\title{
Helichrysi Flos Drogu Üzerinde Farmakognozik Araştırmalar
}

\author{
Pelin TAŞTAN* ${ }^{*}$ \\ Ege Üniversitesi, Eczacılık Fakültesi, Farmakognozi Anabilim Dalı, Bornova, İzmir, Türkiye \\ Geliş / Received: 02/08/2018, Kabul / Accepted: 19/11/2018
}

\begin{abstract}
$\ddot{O} \mathbf{z}$
Ölmez çiçek ismi ile bilinen Helichrysi Flos drogu üzerinde Avrupa Farmakopesi yöntemleri esas alınarak kalite kontrol çalışmaları gerçekleştirilmiş ve drogun kurutmada kayıp miktarı ile sülfat külü miktarı, hidroklorik asitte çözünmeyen kül miktarı ve bütün kül miktarı tayin edilmiştir. Elde edilen verilerin farmakope doğrultusunda kabul edilebilir aralıklarda oldukları tespit edilmiştir. Ayrıca bu drogdan infüzyon yoluyla hazırlanan bitkisel çay preparatları da kullanılarak ağır metal tayini analizleri gerçekleştirilmiştir. Toz drog ve su ekstrelerinin içerdiği ağır metaller incelenerek karşılaştırma yapılmıştır. Buna göre bitkisel verimliliği ve kaliteyi arttıran birçok metalin toz drogtan ekstreye yüksek oranda geçtiği saptanmıştır. Toksik ağır metallerin drogdaki oranının eser miktarda olması, bu çayların güvenli bir şekilde tüketilmesi için önemlidir. Bu da, yapmış olduğumuz çalışma sonucunda elde ettiğimiz anlamlı bir veri olmuştur.
\end{abstract}

Anahtar Kelimeler: Ağır metal, İnfüzyon, Farmakope, Helichrysi Flos.

\section{Pharmacognosic Researches on Helichrysi Flos}

\begin{abstract}
Quality control studies were carried out on Helichrysi Flos which is known with the names of ölmez çiçek, according to European Pharmacopoeia methods. And the amounts of sulphate ash, hydrochloric acid undissolved ash and total amount of ash were determined. It has been determined that the obtained data are in acceptable ranges in Pharmacopoeia. In addition, heavy metal determination analyzes were carried out using herbal teas prepared by infusion of the drog. Heavy metals contained in dried plant powder and water extracts were examined and compared. According to this, it was determined that many metals which increase the plant productivity and quality are higher in powdered plants. The amount of toxic heavy metals in the herbal teas is also important for consumption of these teas safely. This is a meaningful data we have obtained in the work we have done.
\end{abstract}

Keywords: Heavy metal, Infusion, Pharmacopeia, Helichrysi Flos.

\section{Giriş}

Gün geçtikçe hava, toprak ve suda birikme oranı artmakta olan ağır metaller, ekosistem için büyük bir tehdit oluşturmaktadır. Ağır metallerin topraktaki varlı̆̆ verimliliğini olumsuz yönde etkilemekte olup, ayrica hayvan ve insan sağlığı üzerinde de besin zinciri yoluyla olumsuz etkilere sahiptir. Bitkilerde bulunan ağır metaller, bitkilerin fizyolojik aktivitelerini etkilemekte ve verimliliklerini azaltmaktadır. $\mathrm{Bu}$ da kaliteli ürün miktarının azalmasına yol açmaktadır. Bitkilerin ağır metal toksisitesine karşı toleransları birçok etkene bağgl olarak değişmektedir. Bunlardan bazıları bitki türü, içerdiği elementlerin türü, maruz kaldığı stres süresi gibidir. Bu yüzden ağır metallerin türü ve bitkiler içerisinde bulunma kompozisyonu, bitkilerin gelişimi ve verimliliği açısından oldukça önemlidir. Hızla artan dünya nüfusu sebebiyle birim alandan elde edilen kaliteli bitkisel ürün miktarının arttırılması hedefi doğrultusunda, bitkisel ürün üretiminde kalite standartlarının yakalanması ve sağlığı olumsuz etkileyecek uygulamalardan kaçınılması gerekmektedir (Gür vd., 2004). Bu sebeple, bitki ve dolayısıyla insan ve hayvan sağlığını olumsuz yönde etkileyen ağır metallerin, bitkisel ürünlerdeki bileşimi ve 
bulunuşlarının incelenmesi önemli bir husustur.Özellikle çalışmamızda da bu sebeple Türkiye'de eczanelerde satılan diüretik etkiye sahip Helichrysi Flos drogunun çay örneğinin Avrupa Farmakopesi'ne göre kalite kontrol çalışmalarının yapılması hedeflenmiş̧tir.

Resim 1'de görülmekte olan Helichrysi Flos (Helichrysum arenarium
Moench) drogunun, fitoterapide özellikle diüretik özellikleri nedeniyle yaygın olarak Avrupa'da ve Türkiye'de kullanılan tıbbi çaylar ve geleneksel bitkisel ürünlerin içinde yer aldığ bilinmektedir. Değişmeyen bir gerçektir ki tıbbi çaylar içindeki drogların kalite kontrolleri ve ağır metal içerikleri de, piyasada eczanede satılan ürünler için oldukça önemli bir bulgudur.

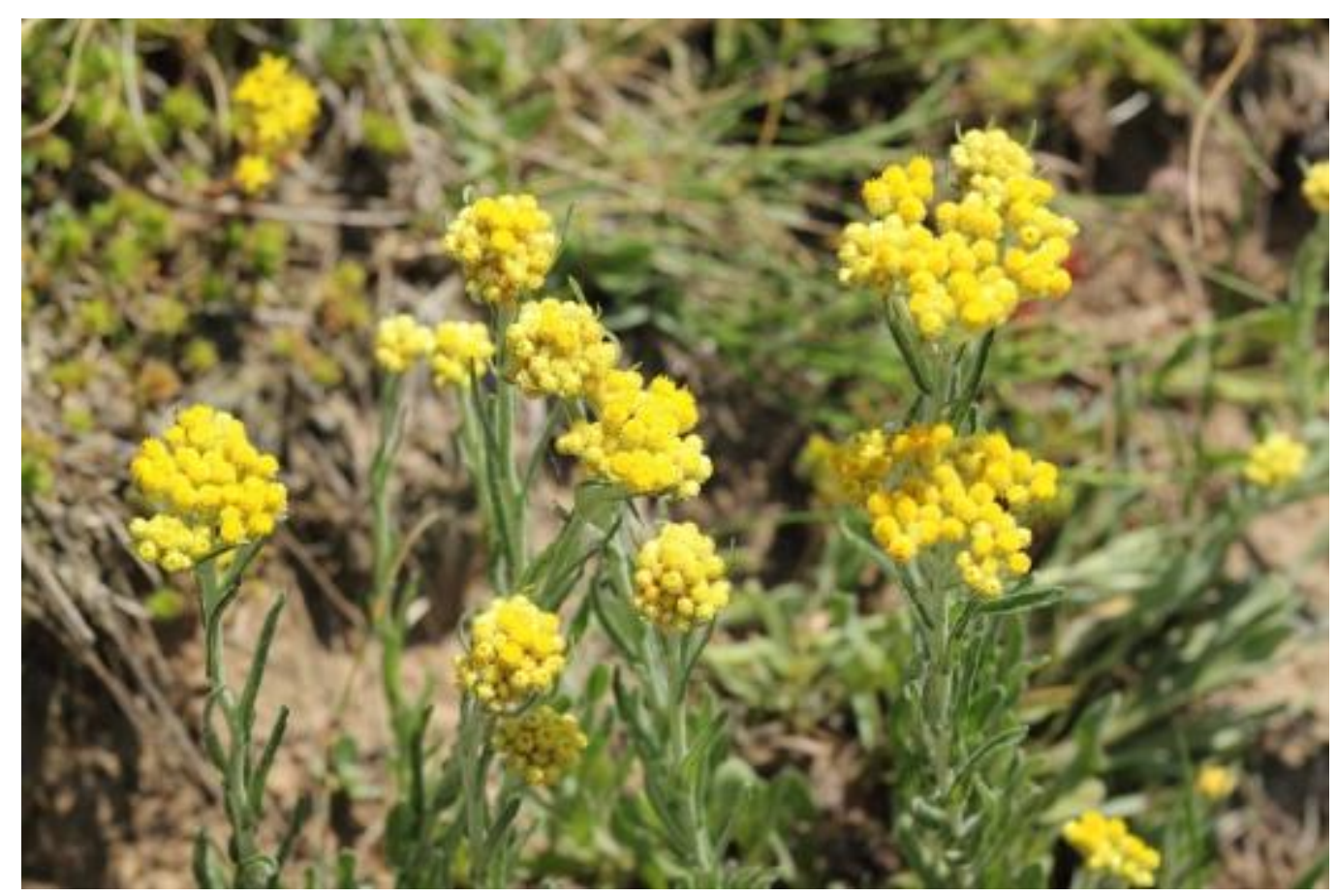

Resim 1. Helichrysum arenarium (L.) Moench) doğadaki görünüşü

Ağır metallerin yayılmasını sağlayan etkenler arasında motorlu taşıt egzozları, volkanik faaliyetler, tarımda kullanılmakta olan ilaçlar, şehir atıkları ve endüstriyel faaliyetler sayılabilmektedir. $\mathrm{Bu}$ ağır metallerden bazıları bitki gelişimi için gerekli iken, bazılarının da bulunuşu bahsettiğimiz olumsuz etkilere sebep olmaktadır (Stresty vd., 1999). Çinko, bakır, nikel, mangan, molibden ve kobalt bitkiler için gerekli elementler arasındadır. Bitki gelişimi üzerinde toksik etkisi olan elementler arasında ise vanadyum, arsenik, alüminyum, kurşun, civa, selenyum ve kadmiyum sayılabilmektedir. Toksik etkili ağır metaller etkilerini bitkilerde stoma hareketleri, transpirasyon, fotosentez, birçok enzim aktivitesi, hormonal denge gibi birçok fizyolojik aktivitenin oluşmasını engelleyerek gösterebilmektedir (Kennedy vd., 1987; Haktanır vd., 1998). 


\section{Materyal ve Metot}

\subsection{Bitkisel Materyal}

Bitkisel çay örneği olarak sadece eczanelerde satılan örnek bir Helichrysi Flos (Helichrysum arenarium (L.) Moench) drogu satın alınmış ve bu örnek üzerinde 3 paralel olacak şekilde planlanarak çalışmalar sürdürülmüştür.

Çay numuneleri içindeki Helichrysi Flos drogu, değirmen kullanılarak toz edilmiştir. $\mathrm{Bu}$ toz drogdan infüzyon yöntemi ile bitkisel çayları elde edilmiştir. Yapılmış olan çalışmalarda, toz drog ve bu drogdan hazırlanmış olan su ekstreleri kullanılmıştır. Toz edilmiş drogtan infüzyon yöntemi ile bitkisel çayın eldesi için; $20 \mathrm{~g}$ toz drog üzerine $200 \mathrm{ml}$ kaynar distile su ilave edilmiştir. Ağzı kapatıldıktan sonra 20 dakika beklendikten sonra, drogla muamele olan çözücü süzülmüştür. Su alçak basınç altında kuruluğa kadar uçurulmuştur.

\subsection{Kalite Kontrol Tayinleri}

Bitkisel drog üzerinde kalite kontrol amaçlı kül ve kurutmada kayıp miktar tayinleri yöntemleri uygulanmıştır. Bunun için Avrupa Farmakopesi yöntemleri esas alınmış ve kurutmada kayıp miktarı ve sülfat külü miktar tayini, hidroklorik asitte çözünmeyen kül miktar tayini ve bütün kül miktar tayini olmak üzere üç ayrı kül miktarının tayini de gerçekleştirilmiş ve drogun kalite ve saflıkları hakkında bilgi sahibi olunmuştur.

\subsubsection{Kurutmada Kayı Miktar Tayini}

Sabit vezne getirilmiş ve darası alınmış cam kroze içerisine konmuş olan birer gram ağırlığındaki Helichrysi Flos drog örnekleri, $100-105^{\circ} \mathrm{C}$ sicaklığındaki etüvde tutulmuştur. 1 saat sonrasında etüvden çıkarılan cam kroze, desikatör içerisinde soğuması için yaklaşık 15-20 dakika kadar bekletilmiş ve soğuduktan sonra tartımı yapılmıştır. İki tartım arasındaki fark, $0.5 \mathrm{mg}$ 'dan fazla olmayana kadar bu işlemlere aynı sıra ile devam edilmiş ve sonuçta drogların kurutmada kayıp miktarları hesaplanmıştır.

\subsubsection{Kül Miktar Tayinleri}

Avrupa Farmakopesi esas alınarak uygulanmış olan kül miktar tayini yöntemleri sülfat külü miktar tayini, hidroklorik asitte çözünmeyen kül miktar tayini ve bütün kül miktar tayini yöntemi şeklindedir.Sülfat külü miktar tayini yöntemi ile materyalde bulunan oksit ve karbonatlar, sülfürik asitin ilavesi ile uçucu olmayan sülfatları haline dönüştükleri için, sonuç olarak sabit değerler elde edilmektedir. Porselen kroze $600 \pm 25^{\circ} \mathrm{C}$ sicaklığındaki Heraeus marka yakma firınında sabit vezne getirilmiştir. Bu kroze içerisine $1 \mathrm{~g}$ Helichrysi Flos toz drogu eklenmiş ve üzerine damla damla, $2 \mathrm{ml}$ kadar \% 10'luk sülfürik asit çözeltisi ilave edilmiştir. $\mathrm{Su}$ banyosunda kurutulduktan sonra tablalı 1sıtıcıda, duman çıkışı sona erene kadar yakılmıştır. Daha sonra porselen kroze, $600 \pm 25^{\circ} \mathrm{C}$ sicaklığındaki yakma firınında 1 saat yakılmıştır ve süre sonunda çıkarılarak desikatör içerisinde soğutulmuştur. Soğuyan krozenin tartımı yapılmıştır. Sonrasında yine drog üzerine 2 $\mathrm{ml} \%$ 10'luk sülfürik asit çözeltisi damla damla eklenmiştir. Arkasından kurutma ve yakma işlemleri aynı sıra ile tekrarlanmıştır. Yine çıarılan kroze desikatörde soğutulduktan sonra yapilan tartım sonrasında, drog üzerine \% 15.8 'lik amonyum karbonat çözeltisi eklenmiştir. Tekrar kurutma ve yakma işlemleri uygulanmıştır. Sırası ile bu yakma, soğutma ve tartım işlemlerine drog külü içeren kroze, sabit vezne gelinceye kadar devam edilmiştir. $\mathrm{Bu}$ şekilde, drogun sahip olduğu yüzde sülfat külü miktarı hesaplanmıştır.Hidroklorik asitte çözünmeyen kül miktar tayini ile toprakta en çok bulunan elementlerden olan silisyum vb. nin varlığı test edilmektedir. Özellikle bitkisel materyalin yol kenarından toplanmış olması, taşıt gazları gibi kirlilikleri içermesi durumunda bu kirliklerin tayini, 
hidroklorik asitte çözünmeyen kül miktarının

Porselen kroze $600 \pm 25^{\circ} \mathrm{C}$ sicaklığındaki Heraeus marka yakma firınında sabit vezne getirilmiştir. Bu kroze içerisine, tam tartılmış 1 g Helichrysi Flos drogu eklenmiştir. 100$105^{\circ} \mathrm{C}$ sicaklığındaki etüvde 1 saat süre ile bekletildikten sonra yakma firınında 1 saat süre ile yakılmıştır. Sonrasında desikatörde soğuması sağlanarak tartımı yapılmıştır. $\mathrm{Bu}$ işlemlere son iki tartım arasındaki fark 0.5 mg'dan fazla olmayıncaya kadar devam edilmiştir. Sonrasında droglar üzerine $15 \mathrm{ml}$ distile su ve $10 \mathrm{ml}$ hidroklorik asit eklenerek, krozenin üstü saat camı ile kapatılmıştır. Tablalı 1sıtıcıda 10 dakika süre ile 1sıtılmıştır. Soğuduktan sonra kül birakmayan süzgeç kağıdından (589 ${ }^{1}$ Black Ribbon) süzülerek süzüntü nötr olana dek, süzgeç kağıdı sıcak distile su ile yıkanmıştır. Süzgeç kağıdı üzerindeki bakiye ile beraber tekrar porselen kroze içerisine konarak tartılmıştır. Sırası ile yakma, soğutma ve tartım işlemlerine, son iki tartım arasındaki fark $0.5 \mathrm{mg}$ 'dan fazla olmayıncaya kadar devam edilmiştir. Bu yöntem ile drogun içerdiği yüzde hidroklorik asitte çözünmeyen kül miktar tayini hesaplanmıştır.Bütün kül miktar tayini yöntemi ile yakılma ile beraber organik maddelerin içerisinde bulunan karbon, karbondioksit haline geçer ve geriye ise inorganik maddeler kalır. Eğer materyal içerisinde kum, taş vb. inorganik kirlilikler var ise inorganik madde miktarı yüksek olacağı için materyalin bütün kül miktarı, yüksek bir değer olarak karşımıza çıkar. Farmakopelerde belirtilen kabul edilebilir tayini

ile

mümkün

olur.

limitler içerisinde yer almayan materyaller ise, kalitesiz olarak kabul edilir. Porselen kroze $600 \pm 25^{\circ} \mathrm{C}$ sıcaklığındaki yakma fırınında sabit vezne getirilmiştir. Bu kroze içerisine 1 g miktarındaki Helichrysi Flos drogu eklenmiştir. $100-105^{\circ} \mathrm{C}$ sicaklığındaki etüvde 1 saat süre ile bekletildikten sonra, $600 \pm 25^{\circ} \mathrm{C}$ sicaklığındaki Heraeus marka yakma fırınında 1 saat süre ile yakılmıştır. Sonrasında desikatörde soğuması sağlanarak, tartımı yapılmıştır. $\mathrm{Bu}$ işlemlere son iki tartım arasındaki fark $0.5 \mathrm{mg}$ 'dan fazla olmayıncaya kadar devam edilmiştir. Drogun içerdiği yüzde bütün kül miktarına, bu şekilde ulaşı1mıştır.

\subsection{Ağır Metal Analizi}

Hazırlanmış olan drog su ekstrelerinin ağır metal analizlerini gerçekleştirmek için XRF analizi yöntemi uygulanmıştır. Bunun için SPECTRO X cihazına sırası ile ölçümleri yapılacak örnekler yerleştirilmiş ve her ölçüm seansında bir örnek kullanılmıştır. Helyum gazı tüpünden cihaza gaz akışı sağlanmıştır. $28 \mathrm{~mm}$ inceliğinde toz halindeki örneklerin dilüsyon faktörü 1 olarak belirlenmiştir.

\section{Bulgular}

\subsection{Kalite Kontrol Tayini Yöntemleri 3.1.1. Kurutmada Kayıp Miktar Tayini}

Helichrysi Flos drogu üzerinde uygulanmış olan kurutmada kayıp miktar tayini analizi sonucunda elde edilmiş olan bulgular, Tablo 1 'de verilmektedir.

Tablo 1. Helichrysi Flos drogunu kurutmada kayıp miktar tayini sonuçları

\begin{tabular}{|c|c|}
\hline $\begin{array}{c}\text { Helichrysi Flos Drog Miktarı } \\
\text { (g) }\end{array}$ & Kurutmada Kayı Miktarı (\%) \\
\hline 1.54 & 29.576 \\
\hline 1.11 & 28.573 \\
\hline 1.55 & 30.014 \\
\hline
\end{tabular}




\subsubsection{Kül Miktar Tayinleri}

1 g Helichrysi Flos drogu üzerinde 3 paralel olarak uygulanmış olan sülfat külü miktar tayini, hidroklorik asitte çözünmeyen kül miktar tayini ve bütün kül miktar tayini çalışmaları sonucunda elde edilmiş olan bulgular, özetlenmektedir (Tablo 2).

Tablo 2. Helichrysi Flos droğu kül miktar tayini sonuçları

\begin{tabular}{|c|c|c|}
\hline $\begin{array}{c}\text { Sülfat külü miktarı } \\
(\boldsymbol{\%})\end{array}$ & $\begin{array}{c}\text { Hidroklorik asitte } \\
\text { çözünmeyen kül miktarı } \\
(\boldsymbol{\%})\end{array}$ & $\begin{array}{c}\text { Bütün kül miktarı } \\
(\boldsymbol{\%})\end{array}$ \\
\hline 27.415 & 3.450 & 25.664 \\
\hline 27.354 & 3.810 & 25.882 \\
\hline 26.859 & 3.741 & 25.209 \\
\hline
\end{tabular}

\subsection{Ağır Metal Analizi}

Bitkisel droglardan hazırlanmış olan ekstrelerdeki ağır metal kompozisyonlarının analizi sonucunda elde edilen bulgular, Tablo 3te verilmektedir.

Tablo 3. Helichrysi Flos toz drogu ve ekstrelerinin ağır metal analizi sonuçları

\begin{tabular}{|c|c|c|}
\hline Element & $\begin{array}{c}\text { Helichrysi } \\
\text { Flos } \\
\text { Toz Drog } \\
\%\end{array}$ & $\begin{array}{c}\text { Helichrysi } \\
\text { Flos } \\
\text { Su Ekstresi } \\
\%\end{array}$ \\
\hline Sodyum (Na) & 12.60 & 15.97 \\
\hline Magnezyum (Mg) & 3.490 & 3.604 \\
\hline Alüminyum (Al) & 2.308 & 1.234 \\
\hline Fosfor (P) & 1.266 & 1.208 \\
\hline Sülfür (S) & 0.4576 & 0.6135 \\
\hline Potasyum (K) & 27.21 & 37.63 \\
\hline Kalsiyum $(\mathrm{Ca})$ & 19.05 & 9.477 \\
\hline $\operatorname{Demir}(\mathrm{Fe})$ & 3.570 & 0.1418 \\
\hline Kobalt (Co) & $<0.00030$ & 0.0042 \\
\hline Nikel (Ni) & $<0.00020$ & 0.00181 \\
\hline Bakır $(\mathrm{Cu})$ & 0.464 & 0.2673 \\
\hline Arsenik (As) & $<0.00010$ & $<0.00010$ \\
\hline Selenyum $(\mathrm{Se})$ & 0.00176 & 0.01032 \\
\hline Molibden (Mo) & 0.0313 & 0.0112 \\
\hline Mangan (Mn) & 0.254 & 0.071 \\
\hline Vanadyum (V) & $<0.00051$ & $<0.00051$ \\
\hline Silikon $(\mathrm{Si})$ & $<0.00051$ & $<0.00051$ \\
\hline Klor $(\mathrm{Cl})$ & 2.928 & 6.422 \\
\hline Titanyum (Ti) & $<0.00051$ & $<0.00051$ \\
\hline Krom $(\mathrm{Cr})$ & $<0.00051$ & $<0.00051$ \\
\hline Çinko (Zn) & 0.1257 & 0.0416 \\
\hline Germanyum $(\mathrm{Ge})$ & $<0.00010$ & $<0.00010$ \\
\hline Kadmiyum (Cd) & $<0.00051$ & $<0.00051$ \\
\hline Kurşun (Pb) & $<0.00020$ & $<0.00020$ \\
\hline Bizmut (Bi) & 0.0282 & $<0.00020$ \\
\hline Lantan (La) & $<0.0010$ & $<0.0010$ \\
\hline
\end{tabular}




\begin{tabular}{|l|c|c|}
\hline Baryum $(\mathrm{Ba})$ & 0.109 & $<0.00081$ \\
\hline Krom $(\mathrm{Cr})$ & $<0.00051$ & $<0.00051$ \\
\hline Brom $(\mathrm{Br})$ & 0.0537 & 0.0567 \\
\hline Stronsiyum $(\mathrm{Sr})$ & 0.0539 & 0.0235 \\
\hline Niyobyum $(\mathrm{Nb})$ & 0.0078 & 0.00228 \\
\hline Antimon $(\mathrm{Sb})$ & $<0.00061$ & $<0.00061$ \\
\hline Civa $(\mathrm{Hg})$ & $<0.00020$ & $<0.00020$ \\
\hline Total & 74.01 & 76.84 \\
\hline
\end{tabular}

\section{Sonuç ve Tartışma}

Elde edilmiş veriler doğrultusunda, drogun kalite kontrol tayinleri gerçekleştirilmiş ve Tablo 1'de gösterilen sonuçların farmakope değerlerine göre kabul edilebilir aralıklarda olduğu tespit edilmiştir. Yapılmış olan 3 paralel teste göre elde edilmiş ortalama kurutmada kayı miktarı, Helichrysi Flos droğu için \% $29.388 \pm 0.738$ olarak tespit edilmiştir.Yine 3 paralel olarak sürdürülmüş kül miktar tayini çalışmaları sonucunda elde edilen, Tablo 2'de görülen incelendiğinde; Helichrysi Flos droğu için sülfat külü miktarı $\% \quad 27.209 \pm 0.304$, hidroklorik asitte çözünmeyen kül miktarı \% $3.667 \pm 0.191$ ve bütün kül miktarı \% $25.585 \pm 0.343$ olarak bulunmuştur. Drogtan infüzyon yöntemi ile hazırlanmış olan bitkisel çay preparatlarında ve toz drogda gerçekleştirilmiş olan ağır metal analizi tayinleri sonucunda elde edilen veriler de Tablo 3'te gösterildiği üzere incelenmiştir. Buna göre her iki drog için de toz drogtan çaya geçen ağır metal miktarları değerlendirilmiştir. Bitki gelişimi ve verimliliği için gerekli olan metallerden olan sodyum, potasyum, magnezyum, kobalt, bakır, mangan, çinko ve nikel gibi metallerin varlığı, toz drogtan daha yüksek miktarda ekstrelerinde saptanmıştır. Bu da, bu drogdan hazırlanmış olan bitkisel çayların, bitkilerin etkilerini göstermesinde daha olumlu etkisi olduğunu göstermiştir. Toz drogta ve su ekstrelerinde en yüksek miktarda gözlenmiş olan potasyum, bitkilerde genel olarak protein sentezi, fotosentez, enzim faaliyetleri ve etkili su kullanımı gibi birçok fizyolojik aktivite için gereklidir. Ayrıca beslenme ve vücuttaki sıv1 ve elektrolit dengesinin sürdürülmesi açısından da oldukça büyük önem taşımaktadır (Martin vd., 1985). Hormon salınımı, sinyal aktarımı, immun yanıt iletimi düzenlemesi gibi birçok faaliyette olumlu etkisi de bulunan potasyumun analizimiz sonucu varlığının tespit edilmiş olması bu yüzden önemlidir (Ekinci vd., 2004; Curran, 1998).Yine hem toz drogda hem de su ekstrelerinde yüksek oranda bulunmuş olan sodyum ve kalsiyumun da birçok hayati hücresel aktivitede rol oynadığı bilinmektedir (Yagi vd., 2013). Majör elementlerden olmasa da insan vücudundaki asit-baz dengesini düzenlediği bilinen klor ve magnezyumun da, toz drogdan daha yüksek miktarda ekstrelerde gözlendiği görülmektedir. Düşük miktarlarda varlığı tespit edilmiş olan çinko ve bakır metalleri de hem toz drogda, hem de ekstrelerinde gözlenmiştir. İnsan ve hayvanlarda olduğu gibi bitkilerde de çok çeşitli metabolik işlevlere sahip olan çinko ve bakır, protein ve karbonhidrat sentezi, enzim aktivasyonu, fotosentez gibi faaliyetler üzerinde gösterdiği etki ile elde edilen ürünün kalite ve verimini etkilemektedir (Rout vd., 2003; Kacar vd., 2006). Birçok endüstri alanında da kullanılan çinko, atık sular ve asit yağmurları aracılığıyla toprağa ulaşmaktadır (Vaillant vd., 2005) etkilerini inceleyen bir çalışmada, konsantrasyonunun artması ile beraber bitki büyümesini azalttı̆̆ tespit edilmiştir (Zengin vd., 2005). Benzer şekilde yüksek miktardaki bakırın da, bitki 
gelişimi için gerekli olan kalsiyumun köklerden yapraklara taşınmasını azalttığ 1 tespit edilmiştir (Sosse vd., 2004). Tıbbi çay olarak kullanılan örnek numunelerinin insan sağlığı açısından da tüketirken ağır metallerin toksik özelliklerinin bilinmesi üzerine, vücutta birikmemesi için düşük miktarda çaylarda olması gerekmektedir. Özellikle kurşun, civa ve kadmiyum çay numunelerinde düşük oranda saptanması, bu çayların güvenli kullanılması açısından da önemli bir sonuçtur.Sonuç olarak yukarıda anlatıldığı üzere bitki kalitesini ve verimliliği

\section{Kaynaklar}

Avrupa Farmakopesi Adaptasyonu Türk Farmakopesi. (2004), 117-265.

Curran, M.E. (1998) Potassium targets, ion channels and human disease: phenotypes to drug. Cur Opin Biotechnol. 9; 565-572.

Ekinci, N., Ekinci, R., Polat, R., Budak, G. (2004) Analysis of trace elements in medicinal plants with energy dispersive $\mathrm{X}$-ray fluorescence. J. Radional Nucl. Chem. 260; 127-131.

Gür, N., Topdemir, A., Munzuroğlu, Ö, Çobanoğlu, D. (2004) Ağır metal iyonlarının $(\mathrm{Cu}++, \mathrm{Pb}++, \mathrm{Hg}++, \mathrm{Cd}++)$ Clivia sp. bitkisi polenlerinin çimlenmesi ve tüp büyümesi üzerine etkileri. Frrat Üniversitesi Fen ve Matematik Bilimleri Dergisi, 16(2), 177-182.

Haktanır, K., Arcak, S. (1998) Çevre kirliliği. Ankara Üni. Ziraat Fak. Toprak Bölümü, Ankara Üni. Yayın no:1503, Ders Kitabı:457, Ankara.

Kacar, B., Katkat, V. (2006) Bitki besleme, Nobel Yayın no:849,.

Kennedy, C.D., Gonsalves, F.A.N. (1987) The action of divalent zinc, cadmium, mercury, copper and lead on the transroot potential and efflux of excised roots. J. Exp. Bot., 38; 800-817.

Martin, D.W., Mayers, P:A., Rodwell, V.W., Granner, D.K. (1985) Harper's Review of Biochemistry, Lange Medcical Publications, California, 651-660. üzerinde pozitif etkileri bulunan birçok ağır metalin toz droglardan su ekstrelerine yüksek oranda geçtikleri saptanmıştır. $\mathrm{Bu}$ da, çalışmamız ile elde ettiğimiz olumlu bir veri olarak karşımıza çıkmıştır.

Rout, G.R., Das, P. (2003) Effect of metal toxicity on plant growth and metabolism: I. Zinc. Agronomie, 23; 311.

Sosse, B.A., Genet, p., Dunand-Vinit, F., Toussaint, L.M., Epron, D., Badot, P.M. (2004) Effect of copper on growth in cucumber plants (Cucumis sativus) and its relationships with carbonhydrate accumulation and changes in ion contents. Plant Science, $166 ; 1213-1218$.

Stresty, T.V.S, Madhava Rao, K.V. (1999) Ultrastructural alterationsin response to zinc and nickel stress in the root cell of pigeonpea. Environ Exp Bot, 41:3-13.

Vaillant, N., Monnet, F., Hitmi, A., Sallanon, H., Coudret, A. (2005) Comparative study of responses in four Datura species to a zinc stress. Chemosphere, 59; 1005-1013.

Yagi, S., Rahman, A.E., Elhassan, G., Abdelhafeez, M.A. (2013) Elemental analysis of ten Sudanese medicinal plants using X-ray fluorescence. J. of Applied and Industrial Sciences. 1(1); 49-53.

Zengin, K.F., Munzuroğlu, Ö. (2005) Fasulye fidelerinin klorofil ve karotenoid miktarı üzerine bazı ağır metallerin etkileri. Furat Üni. Fen ve Matematik Bilimleri Dergisi, 17(1); 164-172. 